\title{
A Back-Casting Knowledge Management Vision for a Digital Platform Ecosystem in Support of Thrivable Communities of Knowledge Workers
}

\author{
Ulrich Schmitt \\ University of Stellenbosch Business School, Bellville, South Africa
}

\begin{abstract}
Aim/Purpose This year marks the $75^{\text {th }}$ anniversary of an article titled 'As we may think'. It envisioned the 'Memex' as a personal device affording the productive use of the accumulated human knowledge. It also allowed for the integration of own augmentations able to be effectively shared with the 'Memexes' of others. This article follows up on Vannevar Bush's still unfulfilled aspiration as well as on current unsustainable Knowledge Management states. What would be today's impact and gestalt of such a digital innovation, and how can it be implemented to serve the wellbeing of humanity?

To answer these questions, we are drafting a Vision for a 'Memex'-inspired novel decentralized Knowledge Management System. Its aim is to strengthen the capabilities and autonomy of individual knowledge workers to become collaborative contributors to and beneficiaries of institutional and societal performances.

Insights or The vision elements are rooted in an advanced-stage design science research Findings project and its conceptualization and prototyping of a novel decentralized knowledge management system. The new perspective taken accounts for notions of entropy, generativity, trans-disciplinarity, and sustainability and aims for a digital platform ecosystem which affords clients with highly diverse skills and ambitions to gainfully utilize its resources and generative potential in their personal and local contexts.

Recommenda- With its focus on a sustainable development path to benefit knowledge workers, tions the back-casting vision methodology applied demonstrates its potential to share the envisaged knowledge management prospects with a wider critical mass of stakeholders as a prerequisite for creating the respective decentralized, more generative knowledge management reality.

Keywords Knowledge Visions, Knowledge Management, Memex, Personal Knowledge Management, Knowledge Worker, Opportunity Divides, General-PurposeTechnology, Disruptive Innovation.

* Corresponding Author

(. Received: Sept.20, 2020 | Revised: Oct. 25, 2020 | Published: Nov. 12, 2020

(C) The Author(s) 2020. Open Access: This article is distributed under the terms of the Creative Commons Attribution 4.0 International License. (https://creativecommons.org/licenses/by-nc/4.0/)
\end{abstract}





\section{AREAS OF CONTRIBUTION}

\begin{tabular}{|c|c|c|c|c|c|}
\hline \multicolumn{6}{|c|}{ Paper Category } \\
\hline$\square$ & Original Research & 区 & Position Paper & $\square$ & Comparative \\
\hline$\square$ & Case Study & $\square$ & Technical Briefs & $\square$ & Opinion \\
\hline$\square$ & Reviews & $\square$ & Student Paper & $\bigotimes$ & Innovation Ideas \\
\hline \multicolumn{2}{|c|}{ Type of Digital Innovation } & \multicolumn{2}{|c|}{ Industry } & \multicolumn{2}{|c|}{ Discipline } \\
\hline 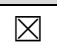 & Radical & $\square$ & Media & 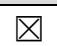 & Business Technology \\
\hline$\square$ & Incremental/Enhancing & $\square$ & Telecom & $\square$ & Human Resources \\
\hline 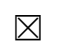 & Disruptive & $\square$ & Consumer Financial Services & $\square$ & Management \\
\hline$\square$ & Breakthrough & $\square$ & Retail & $\square$ & Marketing \\
\hline$\square$ & Basic Research & 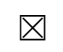 & Technology & $\square$ & Finance \\
\hline 凶 & Sustaining & $\square$ & Insurance & $\square$ & Accounting \\
\hline$\square$ & Architectural & $\square$ & Consumer Products & $\square$ & Computer Science \\
\hline$\square$ & Component/Modular & $\square$ & Non-Profit & $\square$ & Engineering \\
\hline \multirow[t]{13}{*}{$\square$} & Destroying & 凶 & Business/Professional Services & $\square$ & Medicine / Healthcare \\
\hline & & 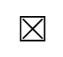 & Higher Education & $\square$ & Law \\
\hline & & $\square$ & K-12 Education & $\square$ & History \\
\hline & & $\square$ & Training & $\square$ & Philosophy \\
\hline & & $\square$ & Health Care & $\square$ & Religion/Theology \\
\hline & & $\square$ & Manufacturing & $\square$ & Mathematics \\
\hline & & & Transportation & $\square$ & Physics \\
\hline & & & & $\square$ & Digital Media \\
\hline & & & & $\square$ & Astrology \\
\hline & & & & $\square$ & Social Sciences \\
\hline & & & & $\square$ & Art and Culture \\
\hline & & & & $\square$ & Psychology/Consciousness \\
\hline & & & & $\square$ & Astronomy \\
\hline
\end{tabular}

\begin{tabular}{|c|c|c|c|c|c|}
\hline \multicolumn{6}{|c|}{ Human Elements } \\
\hline$\square$ & Personality Traits & $\nabla$ & Development & $\square$ & Mental Wellbeing \\
\hline$\square$ & Behaviour & $\square$ & Environmental & $\square$ & Consciousness \\
\hline$凶$ & Cognition & $\bigotimes$ & Social & $\square$ & Physical Wellbeing \\
\hline
\end{tabular}




\section{INTRODUCTION TO VISIONEERING AND THRIVABILITY}

A system's purpose "gives birth to a vision and is often the most crucial determinant of a system's behavior". As interconnected sets of elements which are coherently organized to serve functions or intentions, system visions are encouraging us to go beyond pursuing individual success for the benefit of a sustainable future. Without visioneering (the engineering of a clear vision), "the purposes of subunits may add up to an overall behavior that devastates the whole system" (Kim \& Oki, 2011).

While visioneering incorporates knowledge-creating processes, it may also directly institute a knowledge-related vision as "sets of shared beliefs about how to act and interact to attain some determined idealized future state [by focusing] on the knowledge to be created that goes beyond the existing boundaries" (Nonaka \& Toyama, 2005). A collaborative, outreaching, interdisciplinary approach is suggested to promote vision acceptance and sustainability but may seem unattainable in complex and unpredictable settings. 'Wicked' problems (ill-defined due to incomplete, contradictory, dynamic specifics or interdependencies (Rylander, 2009)), for example, might require pushing for breakthrough innovations where the information needed to understand unfamiliar problem spaces depends on radical ideas and paradigm shifts for solving them.

The design science research (DSR) outcomes - to be repurposed for crafting a 'back-casting' vision - are fitting this latter category. They refer to the ongoing development of a novel knowledge management (KM) system (KMS) aiming for 'theory effectiveness' ${ }^{1}$ by continually reporting on the adopted methodologies and design theories as well as on the evolving artefact and its envisaged technological impact on users, organizations and society. 'Back-casting', as one of the "the most effective futuring methods", facilitates knowledge visions by defining a desirable future from which to work backwards to identify conditions and factors that must be addressed for its realization (Ceruti et al., 2019).

The overarching desire, this article emphasizes, is 'thrivability'. As a step beyond sustainability, thrivability identifies concepts "in which resilience is achieved within systems and communities" by enabling citizens to "realize their maximal potential and prosperity", by encouraging "collaboration and cocreation", and by facilitating "the cultivation of collective wisdom" and "co-developing communities" (Laszlo et al., 2017). But, as "digital technologies have been spreading, digital dividends have not"; KM technologies can make workers only more productive, when they command the know-how to use it (World Bank Group, 2016) and are motivated by incentives to adopt and accept them.

Whilst also evident in the United Nation's Sustainable Development Goals, the respective gaps are hampering emerging knowledge economies by contributing to widening opportunity divides (Drori, 2010; Giebel, 2013) and are calling for a new educational and knowledge-creation (research) orientation. As just memorizing facts no longer provides individual leverage, today's "limited resource has become the creative combination, integration, and useful application of knowledge into networked production and customization" (Laszlo, 2018).

Neither a vision statement nor a vision-related position paper like this can particularize all the designrelated twists and turns considered for the KMS's implementation, nor are they supposed to detail the logics and logistics which shape the overall solution. The back-casting approach adopted, hence, centers on interrelated concise narratives (without in-text citations) but makes the peer-reviewed prior DSR work and external key sources evident in a tabular format at the end of each section with footnotes providing further essential immediate background and definitions.

${ }^{1}$ Theory Effectiveness represents a DSR paradigm which expects designs to be purposeful - both in terms of utility (a matter of content) and communication (a question of presentation) to an audience

(O’Raghallaigh et al., 2011). 
Preceding these vision-related assertions is a visualized bird's-eye view and brief introduction of the decentralized Digital Platform Ecosystem (DPE) which accommodates the novel Personal Knowledge Management System (PKMS) and concept.

\section{Digital Platform Ecosystem \& Personal KM Concept}

Digital Platform Ecosystems (DPE) are generically defined as meta-artefacts which afford clients with highly diverse skills (gifts) and ambitions (ends) to gainfully utilize its resources and generative potential (means) in their personal and local settings (contexts) (Eck \& Uebernickel, 2016). An article-inprogress is using the gifts-contexts-means-ends perspective to point out the additional complexities such a DPE faces compared to organizational KMS.

Figure 1 provides a general bird's-eye view with some details to be later referred to (e.g. memes). It depicts a social actor (bottom) with his/her decentralized Personal KMS digital device as a member of the PKMS user community. The clockwise iterative workflow shows that the voluntary shared individual content is centrally synthesized and curated (middle-left) before it is fed back to the community to facilitate continual cycles. It may also be repurposed as learning assets to foster Personal Learning Environments ${ }^{2}$ (PLE). Adding to the broader DPE context are further interactions with organizational Knowledge and Learning Management Systems (OKMS, LMS).

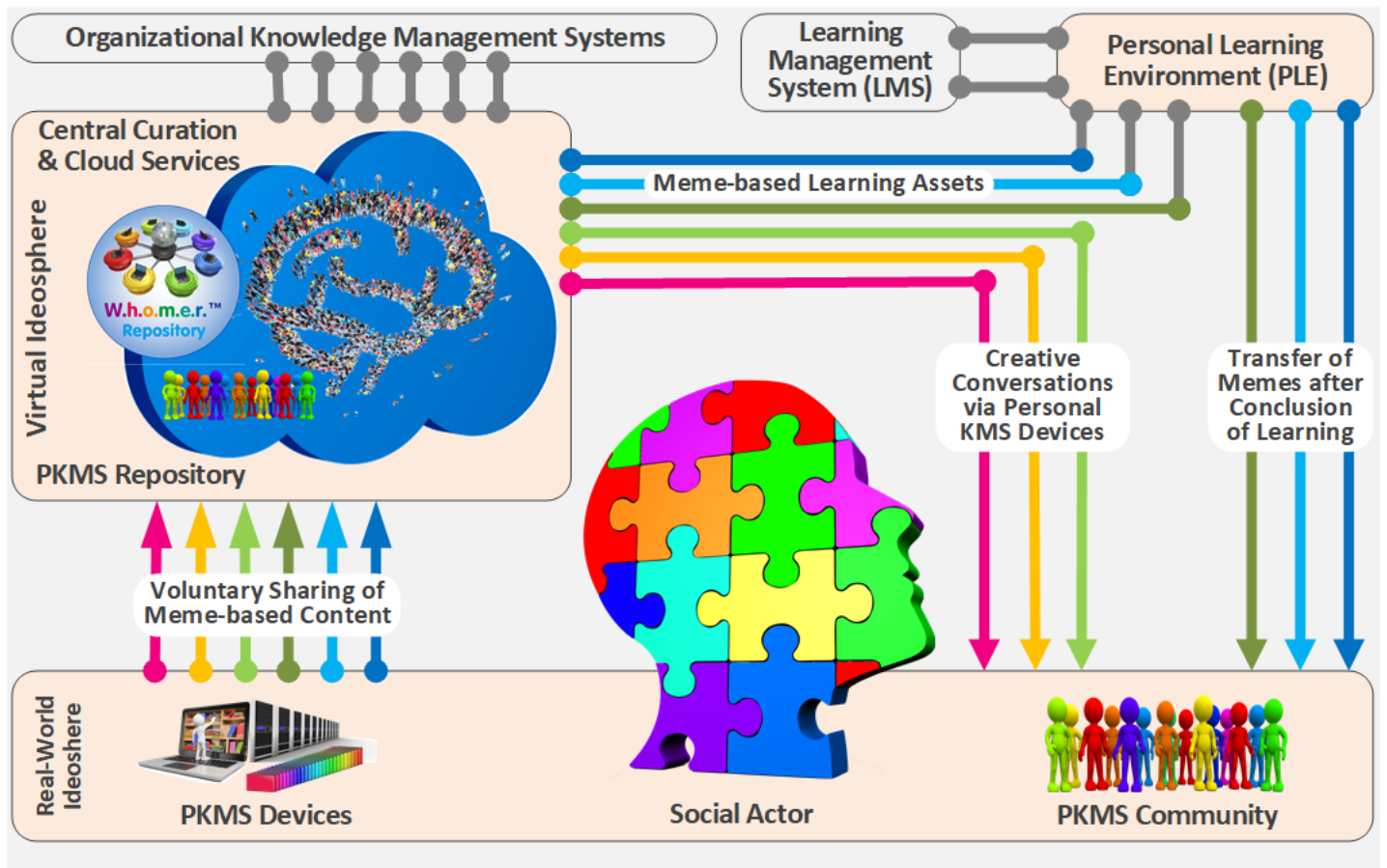

Figure 1. PKMS at the centre of a Digital Platform Ecosystem (DPE) (Schmitt \& Gill, 2019).

${ }^{2}$ Personal Learning Environments (PLE) are defined as (1) Activity spaces encompassing appropriate learning resources (tools, content, people) to support and facilitate personal learning experiences, (2) where learners address their own learning requirements and gain control over learning taking advantage of the provided learning resources, and (3) where content is reused and remixed according to the learner's own needs and interests as well as shared with other learners (Rahimi, 2015). 
The research methodologies applied to result in this DPE conceptualization are rooted in notions of Design Science Research, Informing Science, and Systems Thinking closely aligned to Knowledge Creation and Human Evolution.

Table 1. Tabular Recapitulation of Key Notions, Contributions, and Sources: Methodologies applied.

\begin{tabular}{|l|l|l|l|}
\hline $\begin{array}{l}\text { Primary Emphasis on: } \\
\text { Methodologies applied }\end{array}$ & $\begin{array}{l}\text { Key Models \& Notions } \\
\text { Integrated }\end{array}$ & $\begin{array}{l}\text { Key PKMS Contribu- } \\
\text { tions }\end{array}$ & $\begin{array}{l}\text { Sources \& PKMS Out- } \\
\text { put }\end{array}$ \\
\hline $\begin{array}{l}\text { Design Science Research } \\
\text { \& Informing Science }\end{array}$ & $\begin{array}{l}\text { Theory Effectiveness; Cu- } \\
\text { mulative Synthesis }\end{array}$ & $\begin{array}{l}\text { Meta-Framework with ten } \\
\text { Digital Ecosystems inte- } \\
\text { grating PKMS with Pop- } \\
\text { per's/Nonaka's notions. }\end{array}$ & $\begin{array}{l}\text { (Usher, 1954; Hevner et } \\
\text { al., 2004; O'Raghallaigh et } \\
\text { al., 2011; Schmitt, 2016a) }\end{array}$ \\
\hline Systems Thinking & $\begin{array}{l}\text { Systems Dynamics; Activity- } \\
\text { Based Modeling; Popper's } \\
\text { Three Worlds; Briscoe's } \\
\text { Digital Ecosystems; Gib- } \\
\text { son's Affordances/Fixations }\end{array}$ & $\begin{array}{l}\text { Hybrid modeling by fusing } \\
\text { system dynamics, discrete- } \\
\text { event, and agent-based ap- } \\
\text { proaches with leading mo- } \\
\text { deling \& visualization tool. }\end{array}$ & $\begin{array}{l}\text { (Dawkins, 1976; Popper, } \\
\text { 1978; Briscoe, 2010; Gib- } \\
\text { son, 2014; Schmitt, 2017a, } \\
\text { 2020c) }\end{array}$ \\
\hline $\begin{array}{l}\text { Knowledge \& Human } \\
\text { Evolution }\end{array}$ & $\begin{array}{l}\text { Knowledge Types; Memes } \\
\text { \& Memetics; Co-evolution- } \\
\text { ary Drivers; Creative Class }\end{array}$ & $\begin{array}{l}\text { Human Civilization as a } \\
\text { five-stage-co-evolution be- } \\
\text { tween social \& physical } \\
\text { knowledge technologies } \\
\text { with PKMS as next driver. }\end{array}$ & $\begin{array}{l}\text { (Dawkins, 1976; Koch, } \\
\text { 2001; Beinhocker, 2006; } \\
\text { Florida, 2014; Schmitt, }\end{array}$ \\
\hline
\end{tabular}

\section{TRANSFORMATIONAL AND DESIRABLE KM VISION}

\section{KNOWLEDGE WORKERS AS AutONOMOUS MEMBERS OF INSTITUTIONS AND SOCIETY}

We regard knowledge workers as self-motivated individuals who continually strive to understand the world and take responsibility for driving improvements. To successfully transform their innumerable small 'nano-actions-and-contributions' into viable institutional performances, any thriving knowledge society needs to encourage their knowledge workers' active participation by empowering their capability potentials.

We envisage Personal KM Systems as autonomous but interconnected artefacts (digital devices, tool kits, repositories, and knowledge assets ${ }^{3}$ ) with six progressing levels of utility:

1. At the most basic level, access to information and knowledge is assured via digital networked KMS devices providing effective and affordable connectivity (representing the current emphasis of efforts for sustainable societal ICT for Development (ICT4D) investments).

2. which facilitate individuals' learning and authorship and allow for developing and articulating own ideas based on one's personal knowledge, expertise, and contexts and inspired by the digital content from the PKMS community's shared central repository (as a foundation for a

${ }^{3}$ Knowledge Assets represent "nonphysical claims to future value or benefits" (Dalkir, 2011). 
society pursuing life-long learning and cultural identity based on nurture (e.g. education) or nature (environmental affordances, kinship)).

3. Since knowledge, as part of reality, is socially constructed, each personal artefact affords its user creating and maintaining social ties to engage with relevant peers of the digital PKMS community in order to augment his/her creativity (as societal means to foster creative conversations and accumulate social resources/capital).

4. It, moreover, eases voluntary personal contributions to the world's knowledge heritage and respective discourses as represented in the shared PKMS central digital repository (as a societal backbone for valuing and sustaining individual freedoms, mastery, and innovativeness).

5. Its digital connectiveness allows for transcending self-actualizing foci by furthering causes, ideals, or others' ambitions beyond self. Users are enabled to collaboratively interlink and collectively harvest prior accumulated knowledge subsets for mutual benefits (as a societal opportunity to promote their citizens generative role as contributors to and beneficiaries of organizational and societal performances).

6. Ultimately, its dynamic networked configurations and deployments provide support for professionals and their stakeholders to form and/or support institutions ${ }^{4}$ and underpin organizational intelligence and digital extelligence ${ }^{5}$ for exploration and exploitation (as a knowledge society's enabler/driver for transforming into a knowledge economy).

Table 2. Tabular Recapitulation of Key Notions, Contributions, and Sources: Knowledge Workers \& Societies.

\begin{tabular}{|l|l|l|l|}
\hline $\begin{array}{l}\text { Primary Emphasis on: } \\
\text { Knowledge Workers }\end{array}$ & $\begin{array}{l}\text { Key Models \& Notions } \\
\text { Integrated }\end{array}$ & $\begin{array}{l}\text { Key PKMS Contribu- } \\
\text { tions }\end{array}$ & $\begin{array}{l}\text { Sources \& PKMS Out- } \\
\text { put }\end{array}$ \\
\hline $\begin{array}{l}\text { Sustainable Development, } \\
\text { ICT4D, and SDGs }\end{array}$ & $\begin{array}{l}\text { Maslow's Hierarchy of } \\
\text { Needs; Johri's ICT4D-De- } \\
\text { sign Framework; Giebel's } \\
\text { Opportunity Divides; Com- } \\
\text { puterization of non-routine } \\
\text { tasks }\end{array}$ & $\begin{array}{l}\text { PKM for Development } \\
\text { Framework (PKM4D) with } \\
\text { progressing individual de- } \\
\text { velopment states \& societal } \\
\text { intervention levels. }\end{array}$ & $\begin{array}{l}\text { (Koltko-Rivera, 2006; } \\
\text { Johri \& Pal, 2012; Giebel, } \\
\text { 2013; Frey \& Osborne, } \\
\text { 2013; Schmitt, 2016b) }\end{array}$ \\
\hline $\begin{array}{l}\text { Capacity Building; Explora- } \\
\text { tion, Exploitation, \& Am- } \\
\text { bidexterity }\end{array}$ & $\begin{array}{l}\text { Attention Management; Ex- } \\
\text { tended Ignorance Model } \\
\text { Map; Snowden's Cynefin } \\
\text { Model; Experiential Learn- } \\
\text { ing; Experience Manage- } \\
\text { ment }\end{array}$ & $\begin{array}{l}\text { PKM for Empowerment } \\
\text { Framework (PKM4E) incl. } \\
\text { unknown-known-dynamics } \\
\text { \& interventions. }\end{array}$ & $\begin{array}{l}\text { (Simon, 1971; Kerwin \& } \\
\text { Witte, 1983; Snowden, } \\
\text { 2002; Kolb, 2014; Schmitt, } \\
\text { 2017c, 2018a) }\end{array}$ \\
\hline $\begin{array}{l}\text { Participation in Network } \\
\text { Community-Building, Col- } \\
\text { laboration, and Social } \\
\text { Knowledge Sharing }\end{array}$ & $\begin{array}{l}\text { Affordances of Past and } \\
\text { Next Community-oriented } \\
\text { Technologies }\end{array}$ & $\begin{array}{l}\text { Repurposing, restructuring, } \\
\text { and extension of prior af- } \\
\text { fordances frames to ac- } \\
\text { commodate PKMS needs. }\end{array}$ & $\begin{array}{l}\text { (Mynatt et al., 1998; } \\
\text { Cabitza et al., 2015; } \\
\text { Schmitt, 2017a, 2017d) }\end{array}$ \\
\hline
\end{tabular}

${ }^{4}$ Institutions are defined as "snapshots of a subset of the ideational field that persevere while the network itself continues to fluctuate" (Kanengisser, 2014).

${ }^{5}$ Extelligence refers to the world's externally stored information; it represents any cumulative archive of human cultural experience and know-how. As the external counterpart to the intelligence of human brains/minds, it provides information for the intelligences' understanding in a complicit process of accelerating interactive co-evolution to be accessible and augmentable by any individual who knows how (Stewart \& Cohen, 1999). 


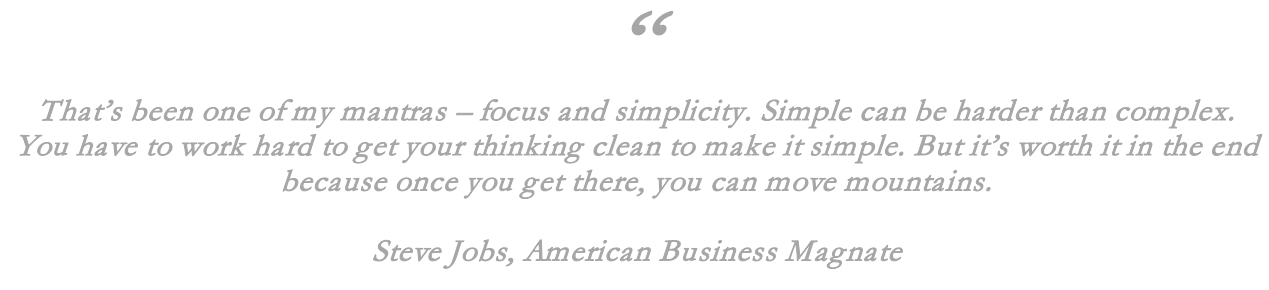

\section{AFFordances CONFERRED TO PKMS COMMUNITY MEMBERS AND STAKEHOLDERS}

We envisage KMSs to be at the center of a Digital Platform Ecosystem (DPE) serving a diverse community in respect to skills and experiences, contexts and means, ambitions and ends (figure 1). Aligned to the six levels of utility presented in the previous sub-section, these affordances include:

1. Effective Digital Technologies: The provision of affordable autonomous decentralized 'grassroots' PKMS digital devices for personal knowledge management and retention, of interconnectivity for creative conversations and cooperative work, of centralized cloud-based storage and curation services for access to the voluntarily shared community's content repositories.

2. Shielded Extelligence: The confidence that one's personal digitized knowledge stays always in the possession and at the personal disposal of its owner or eligible co-worker independent of changes in one's social, educational, professional or technological environment. Moving from one project or responsibility to another embodies one's actualized PKMS device and finally renders the notion of knowledge and skills as mobile and portable a reality for individuals.

3. Productive Collaboration: The universality of the standardized, consistent, transparent, flexible, secure and non-redundant formatting of digitized information structures for easing authoring, retrieval, expansion, sharing, pooling, re-use, or migration (based on meme-based repositories instead of document-centric knowledge bases to be referred later).

4. Systemic Development: The coherency and plausibility of the PKMS concept and design for allowing transparent interventions and systematic informing options and for lowering any entry barriers regarding participating in and contributing to the community.

5. Professional Relevance: The across-the-board applicability for continuous life-cycle support from trainee, student, novice, or mentee to professional, expert, coach or leader independent of space (e.g. developed/developing countries), time (e.g. study or career phase), discipline or economic sector (e.g. science, academia, industry, entrepreneurs, or public service).

6. Co-evolutionary Synergies: Shared KM concepts and methodologies, common interest in the world record and in staying current and resilient present strong incentives for fruitfully coevolving organizational and personal KMS. Motivating knowledge workers by serving their PKMS self-interests also raises the acceptance of institutional KM objectives as well as organizational capabilities of purposefully creating, extending, or modifying its absorptive capacity $^{6}$ and resource base ${ }^{7}$. Similar synergies also exist between PKMS and Learning Management Systems (LMS).

${ }^{6}$ Absorptive Capacity has been defined as the "ability to recognize the value of new information, assimilate it, and apply it to commercial ends" (Cohen \& Levinthal, 1990).

${ }^{7}$ Resource Base, in the context of this article, includes tacit (attitude and leadership), explicit (knowledge bases, rules and strategies), and encapsulated knowledge (products and services) as well as its wider ecosystem (involvement with the community). 
Table 3. Tabular Recapitulation of Key Notions, Contributions, and Sources: Affordances and Education.

\begin{tabular}{|c|c|c|c|}
\hline $\begin{array}{l}\text { Primary Emphasis on: } \\
\text { Affordances, Education }\end{array}$ & $\begin{array}{l}\text { Key Models \& Notions } \\
\text { Integrated }\end{array}$ & $\begin{array}{l}\text { Key PKMS Contribu- } \\
\text { tions }\end{array}$ & $\begin{array}{l}\text { Sources \& PKMS Out- } \\
\text { put }\end{array}$ \\
\hline $\begin{array}{l}\text { Information Entropy } \\
\text { Digital Threats \& Interven- } \\
\text { tions }\end{array}$ & $\begin{array}{l}\text { SVIDT-Framework; } \\
\text { Negentropy \& Syntropy }\end{array}$ & $\begin{array}{l}\text { Cohesive rationalization of } \\
\text { current KMS's neglect of } \\
\text { personal, generative, \& } \\
\text { negentropic needs with } \\
\text { consequences \& remedies. }\end{array}$ & $\begin{array}{l}\text { (Scholz, 2017; Schmitt, } \\
\text { 2018b; Schmitt \& Gill, } \\
\text { 2020) }\end{array}$ \\
\hline Higher Education (HE) & $\begin{array}{l}\text { Qualification Frameworks; } \\
\text { Bloom's Taxonomy; Aca- } \\
\text { demic Value Chain }\end{array}$ & $\begin{array}{l}\text { Making the Case for revis- } \\
\text { ing HE Program \& Ser- } \\
\text { vices Portfolios and Com- } \\
\text { mitments via PKMSs. }\end{array}$ & $\begin{array}{l}\text { (Blass \& Hayward, 2014; } \\
\text { Schmitt \& Butchart, 2014) }\end{array}$ \\
\hline e-Learning \& e-Skills & $\begin{array}{l}\text { Digital Scholarship \& Cura- } \\
\text { tion }\end{array}$ & \multirow{2}{*}{$\begin{array}{l}\text { PKM for Learning Frame- } \\
\text { work (PKM4L-in-progress) } \\
\text { to promote non-linear e- } \\
\text { Learning approach as a } \\
\text { spin-off of novel PKMS } \\
\text { concept. }\end{array}$} & $\begin{array}{l}\text { (Schmitt, 2015b, 2015c, } \\
\text { 2014a) }\end{array}$ \\
\hline $\begin{array}{l}\text { Learning Management Sys- } \\
\text { tems (LMS) \& Learning } \\
\text { Assets }\end{array}$ & $\begin{array}{l}\text { Smart Education Concepts; } \\
\text { Interoperability }\end{array}$ & & $\begin{array}{l}\text { (Schmitt, 2016c; Schmitt } \\
\text { \& Saadé, 2017; Schmitt, } \\
\text { 2019c) }\end{array}$ \\
\hline
\end{tabular}

\section{6 \\ Making the simple complicated is commonplace; making the complicated simple, awesomely simple, that's creativity. \\ Charles Mingus, American Jazz Pianist}

\section{ENABLING TECHNOLOGIES AND GENERATIVE KNOWLEDgE BASES}

We envisage, as briefly alluded to, a paradigm shift from today's document-centric 'book-age' storage tradition to meme ${ }^{8}$-based 'digital-age' repositories. By digitally embedding and reusing parts of digital documents via structural references, the meme-based approach abandons 'book-age' copy-and-paste digital document creation practices and the underlying knowledge heritage model which generates unsustainable attention-and-resource-consuming entropy (e.g. replication, fragmentation, inconsistency, untraceability, corruption, decay, obsolescence, or falsification) at an accelerating scale.

PKMS community members are, accordingly, guided in digitally capturing, creating, modifying, classifying, combining, and accessing textual and visual memes and their relationships to be stored in personal and - if voluntarily shared - centralized repositories. The associatively interlinked content comprises subject matter (e.g., parts of this paragraph, citations, or visuals), aboutness (e.g., article review, wordcount, or author's profile), structural connections (e.g., links between authors, papers, publishers, and references), intent (e.g., tasks to do), and monitoring (e.g., schedules, to-do-lists, progress made).

${ }^{8}$ Memes present a scheme of (atomic) cognitive information-structures that evolve over time through a Darwinian process of variation, selection and transmission. By employing the metaphor of living organisms, they self-replicate utilizing mental storage in human hosts by influencing their hosts' behavior to promote further replication. Memes are virtual, and have no intentions of their own, they are merely pieces of information in a feedback loop which are encoded in vehicles for transmission between human hosts; this loop facilitates their continued replication as mental copies with their longevity being determined by their environ-ment (Dawkins, 1976; Bjarneskans et al., 1999; Collis, 2003). 
Table 4. Tabular Recapitulation of Key Notions, Contributions, and Sources: Undesired Entropy Clusters.

\begin{tabular}{|l|l|l|l|}
\hline $\begin{array}{l}\text { Primary Emphasis on: } \\
\text { Entropy Clusters }\end{array}$ & $\begin{array}{l}\text { Key Models \& Notions } \\
\text { Integrated }\end{array}$ & $\begin{array}{l}\text { Key PKMS Contribu- } \\
\text { tions }\end{array}$ & $\begin{array}{l}\text { Sources \& PKMS Out- } \\
\text { put }\end{array}$ \\
\hline $\begin{array}{l}\text { Public Knowledge } \\
\text { Discoverable }\end{array}$ & $\begin{array}{l}\text { Information Entropy } \\
\text { Copy-\&-Paste Redundancy, } \\
\text { Traceability }\end{array}$ & $\begin{array}{l}\text { - Information Overload, } \\
- \text { Attention Poverty, } \\
+ \text { Compromised Mobility }\end{array}$ & $\begin{array}{l}\text { (Bush, 1945; Simon, 1971; } \\
\text { Pinheiro, 2004; Schmitt, } \\
\text { 2020a) }\end{array}$ \\
\hline $\begin{array}{l}\text { Public Knowledge } \\
\text { Undiscoverable }\end{array}$ & $\begin{array}{l}\text { Structural Holes, } \\
\text { Islands and Siloes } 10\end{array}$ & $\begin{array}{l}\text { - Opportunity Divides } \\
+ \text { Effective Utilization, } \\
+ \text { Awareness \& Education, }\end{array}$ & $\begin{array}{l}\text { (Burt, 2004; Levy, 2011; } \\
\text { Giebel, 2013; Szostak et } \\
\text { al., 2016; Schmitt, 2020a) }\end{array}$ \\
\hline $\begin{array}{l}\text { Private Knowledge } \\
\text { Undiscoverable }\end{array}$ & $\begin{array}{l}\text { Invisible Work, } \\
\text { Unreported Scaffolding11 }\end{array}$ & $\begin{array}{l}\text { - Unproductive Rework, } \\
+ \text { Holistic Understandings }\end{array}$ & $\begin{array}{l}\text { (Bush, 1945; Star, 2010; } \\
\text { Schmitt, 2020a) }\end{array}$ \\
\hline $\begin{array}{l}\text { Private Knowledge } \\
\text { Discoverable }\end{array}$ & $\begin{array}{l}\text { Generative Potential, Online } \\
\text { and Publishing Realities }\end{array}$ & $\begin{array}{l}\text { + Iterative Improvement } \\
+ \text { Innovativeness } \\
+ \text { Reputation Systems }\end{array}$ & $\begin{array}{l}\text { (Bush, 1945; Mintzberg, } \\
\text { 2005; Nielsen, 2012; Brati- } \\
\text { anu, 2019; Schmitt, 2019b) }\end{array}$ \\
\hline
\end{tabular}

\author{
66 \\ Everything should be made as simple as possible, but not simpler. \\ Albert Einstein, Theoretical Physicist
}

Due to the PKMS's standardized memetic format, content is stored in a flat-file WHOMER-repository (World Heritage of MEmes Repository (figure 1)) allowing for scaling by enabling the use of noSQL technologies. Curation services merge identical memes (reducing entropy), conserve and consolidate their bi-directional relationships (enriching traceability) and assure self-referential associative integrity (emulating as-built-genealogies ${ }^{13}$ ). Accordingly, we expect to overcome the inherent shortcomings of the 'book-age' paradigm resulting in reducing negative (-) effects and encouraging positive $(+)$ advances (Table 4$)$.

\footnotetext{
9 The complexity of navigating and utilizing the mounting explicit accumulated world record is accelerating and is overwhelming traditional top-down KM approaches (developed in a time of information scarcity). Advice to prevent today's shortcomings were voiced but ignored, for example, Bush suggesting associative indexing to build the 'Memex' (Bush, 1945) or Simon calling to extract the redundancy and to exploit the patterns of the world record ensuring that considerable less needs to be read, written, and stored (Simon, 1971).

10 Structural Holes refer to unrecorded, potentially beneficial ties between knowledge clusters resulting in disconnected undiscoverable public knowledge (islands and silos) inhibiting, especially, the tackling of 'wicked' transdisciplinary spaces (Burt, 2004; Szostak et al., 2016).

11 Reviewing and publishing practices currently prevent the sharing of "magnitudes of invisible work" (defined as the "gap between formal representations, including publications, and unreported 'back stage' work" (Star, 2010) also referred to as "scaffolding" (Bush, 1945). As undiscoverable private content knowledge, others are forced to re-spend the energy and to start over.

12 On-line publishing realities currently inhibit engaging in a wider sharing, faster diffusion, and more rapid iterative improvement of ideas, sources, data, work-in-progress, preprints, and/or code (Nielsen, 2012). 13 As-built-genealogies form already the heart of modern manufacturing systems which define and trace the technical interrelatedness of discrete parts, ingredients, and labor with their intermediate and final products, services, and/or utilizations (Pinheiro, 2004)).
} 


\section{PKMS-DPE as Scalable General-Purpose TeChNology}

Table 5. Tabular Recapitulation of Key Notions, Contributions, and Sources: Knowledge Creation \& Management

\begin{tabular}{|c|c|c|c|}
\hline $\begin{array}{l}\text { Primary Emphasis on: } \\
\text { Knowledge Creation }\end{array}$ & $\begin{array}{l}\text { Key Models \& Notions } \\
\text { Integrated }\end{array}$ & $\begin{array}{l}\text { Key PKMS Contribu- } \\
\text { tions }\end{array}$ & $\begin{array}{l}\text { Sources \& PKMS Out- } \\
\text { put }\end{array}$ \\
\hline $\begin{array}{l}\text { PKM versus Traditional } \\
\text { Dynamic Knowledge Crea- } \\
\text { tion Models }\end{array}$ & $\begin{array}{l}\text { Nonaka's SECI Model \& } \\
\text { Ba; Pirolli's Sensemaking } \\
\text { Model; Boisot's 3D-Infor- } \\
\text { mation Space; and others }\end{array}$ & $\begin{array}{l}\text { PKM for Action Frame- } \\
\text { work (PKM4E) as a three- } \\
\text { dimensional dynamic 'pub- } \\
\text { lic-transport-like' map ho- } \\
\text { listically portraying com- } \\
\text { plementing KM work- } \\
\text { flows. }\end{array}$ & $\begin{array}{l}\text { Popper, 1978; Nonaka et } \\
\text { al., 2000; Boisot, 2004; Pi- } \\
\text { rolli \& Card, 2005; } \\
\text { Wierzbicki \& Nakamori, } \\
\text { 2007; Schmitt, 2017b, } \\
\text { 2019a) }\end{array}$ \\
\hline $\begin{array}{l}\text { PKMS-OKMS-Co-evolu- } \\
\text { tion; Individual \& Institu- } \\
\text { tional Absorptive Capaci- } \\
\text { ties; Entrepreneurship }\end{array}$ & $\begin{array}{l}\text { KM System Generations; } \\
\text { Earl's Schools of KM; Wiig's } \\
\text { Nano-Contributions; } \\
\text { Growth-Stage Models; Dy- } \\
\text { namic State Matrix }\end{array}$ & $\begin{array}{l}\text { PKM for Management } \\
\text { Framework (PKM4M) for } \\
\text { integrating the PKMS with } \\
\text { Earl's seven Schools and } \\
\text { operative ERM Systems. }\end{array}$ & $\begin{array}{l}\text { (Garnsey, 1998; Earl, 2001; } \\
\text { Pollard, 2008; Levie \& } \\
\text { Lichtenstein, 2009; Pasher } \\
\text { \& Ronen, 2011; Wiig, } \\
\text { 2011; Schmitt, 2015a, } \\
\text { 2016d, 2018c) }\end{array}$ \\
\hline $\begin{array}{l}\text { Heritage Knowledge \& } \\
\text { Generativity; Knowledge } \\
\text { Assets \& Intellectual, So- } \\
\text { cial, \& Emotional Capital; } \\
\text { Scaling }\end{array}$ & $\begin{array}{l}\text { Memex \& Associative In- } \\
\text { dexing; Decentralizing KM } \\
\text { Revolution; Reinventing } \\
\text { Discovery; C-K-Design } \\
\text { Theory; Culinary Knowledge } \\
\text { Heritage; Scaling Innovation }\end{array}$ & $\begin{array}{l}\text { Development of a PKMS } \\
\text { prototype based on rapid } \\
\text { development platform, } \\
\text { cloud-based no-SQL data- } \\
\text { base, and networked de- } \\
\text { centralized personal } \\
\text { PKMS devices. }\end{array}$ & $\begin{array}{l}\text { (Bush, 1945; Erikson, } \\
\text { 1950; Bush, 1991; Gratton, } \\
\text { 2011; Levy, 2011; Nielsen, } \\
\text { 2012; Eck, 2018; Carvajal- } \\
\text { Pérez et al., 2018; Schmitt } \\
\text { \& Gill, 2019; Schmitt, } \\
\text { 2019b, 2020b) }\end{array}$ \\
\hline $\begin{array}{l}\text { Disruptive Innovation \& } \\
\text { Sustainability Vision* } \\
\text { * currently under review }\end{array}$ & $\begin{array}{l}\text { General-Purpose Technolo- } \\
\text { gies GPT; Desirable Sustain- } \\
\text { ability Vision; Development } \\
\text { \& Visioneering }\end{array}$ & $\begin{array}{l}\text { PKM for Innovation } \\
\text { Framework (PKM4I) fus- } \\
\text { ing GPT \& Vision Criteria } \\
\text { to project PKMS potential } \\
\text { in marketplace. }\end{array}$ & $\begin{array}{l}\text { (Garon, 2011; Cantner \& } \\
\text { Vannuccini, 2012; Wiek \& } \\
\text { Iwaniec, 2014; Kaiser, } \\
\text { 2017; Schmitt, 2019d) }\end{array}$ \\
\hline
\end{tabular}

$$
\begin{aligned}
& \qquad 66 \\
& \text { If you want to find new ways, and everything seems barred, take things deemed very simple, } \\
& \text { and make them very smart. } \\
& \text { Adapted from one of my former professors, Exkart Zwicker, TU Berlin }
\end{aligned}
$$

We, consequently, envision the transformation of Popper's abstract, intangible, inaccessible World Three ${ }^{14}$ into a steadily growing (expanding community sharing existent and novel content), single

14 Popper applied his three-world-metaphor to depict knowledge creation flows between the physical world:1 (concrete related knowledge objects and effects) and the human minds' world:2 (subjective 'mental thought' knowledge objects). He introduced world:3 (abstract objective 'explicit thought' knowledge objects) to serve his conviction that thoughts — in or-der to be shared or critiqued — need to be explicated, so that the formulated content stands objectively on its own (independent of its creators and able to be judged on its own merit). As a mere philosophical construct, Popperian world:3 content still needs to be resourcefully combined and physically encapsulated (or encoded) in concrete physical objects to transform the concrete world: 1 environment (or other world:2 minds) in order to activate its generative potential (Popper, 1978). 
(cloud-based), unified (transdisciplinary), negentropic (redundancy-eliminating), concrete, tangible, accessible, and interrogatable archive of an up-to-date knowledge heritage.

\section{DisCUSSION \& CONCLUSIONS}

Facilitating fruitful knowledge sharing to gainfully utilize digital dividends, as alluded to, does not depend on technological means alone but on a range of affordances which are currently sadly missing. Accommodated by a series of prior publications supporting an ongoing design-science-research and KMS-prototyping-project, this article has presented the back-casting vision of a novel decentralized, generative, negentropic KM concept. It substantially departs from conventional centralized institutional KM solutions by strengthening individuals' developmental and collaborative means.

As 'digital-age' knowledge workers with their distinct contexts and ambitions are not only striving to develop unique artefacts (knowledge assets) but are also inclined to voluntarily and freely reveal them to others to use, a new culture of open access and open science is taking hold. A growing PKMS community can significantly add to such a 'thrivable' culture through actionable transparency. While "the emerging artefacts can be easily understood (are transparent) by other contributors and allow real-time iteration due to rapid generate-test cycles ${ }^{15}$ (are actionable)", users are growing in sophistication, and innovation "starts to be dispersed among many creative and entrepreneurial individuals" enabled by opportunities to provide incremental as well as radical advances (Roszkowska-Menkes, 2017).

These outcomes also benefit institutional interests and offer synergies for a fruitful co-evolution between the novel PKMS and conventional organizational KMS. As a structural confirmatory factor analysis model has shown, knowledge sharing excels with higher job satisfaction (depending on an enabling collaborative culture) which, in turn, promotes knowledge distribution, with, both, becoming strong mediators between facets of organizational culture and institutional performances $(\mathrm{Ku}-$ charska \& Bedford, 2019). Empirical proof also confirms that a collaborative culture forms a mutually beneficially strong bond with trust (Kucharska, 2017).

Both, a compelling culture and thriving trust, are also vital for successfully growing a PKMS community. However, trust (defined as a "bet about the future contingent actions of others" (Sztompka, 2019) "cannot be afforded directly but has to be earned by acquiring a reputation of, for example, expertise, professionalism, reliability," or high-quality services/content supplied which may all be within the reach of the envisioned PKMS-DPE affordances (Schmitt, 2017a). This position paper's early draft of a back-casting vision with its 'thrivability' context aims to initiate a suitable informing strategy to address a wider audience as well as to steadily build the vital trust which may come with it. The key aim of the curated repository adds to this endeavor by "providing the PKMS community with non-redundant multi-and-trans-disciplinary memes and knowledge assets which can be trusted and can be traced and accessed through the captured and shared path trajectories just like components, ingredients, or batches in modern manufacturing enterprise resource systems" (Schmitt, 2018c).

Currently, many are not even aware of the dire and unsustainable extent to which knowledge workers and societies are missing out on the full potential of the digital revolution by suffering from lock-in

\footnotetext{
${ }^{15}$ Rapid generate-test cycles in the PKMS context mean that any user-authored meme/content voluntarily shared with the PKMS community afford other members the opportunity to annotate, redeploy, reclassify, or revise it while any new links or versions created in this process feed back to the original author/modifier (assured by the PKMS's central curation services of their associative integrity). Termed 'creative conversations' (Levy, 2011), these functionality allows for rapid iterative improvement among peers based on the interlinked PKMS-managed memeplex versions.
} 
effects, self-centered business interests, and solutions providing objectionable cost-benefits to individuals, entrepreneurs, and employers. Initially faced with these kinds of 'emerging complexities ${ }^{16}$ ', the DSR knowledge base and multi-disciplinary publications have been progressing on cumulatively synthesizing over 600 referenced external sources (as of October 2020). The approach allows for verifying new conceptual or design elements comprehensively, since any effective change process needs to holistically consider its potential interdependencies ${ }^{17}$.

The five tables complementing the interrelated vision narratives exemplify some of these peer-reviewed prior publications with some of their integrated notions and cited primary sources. They are presented in eighteen distinct key clusters to support the higher-level vision-related assertions made with access to further detail, evidence, and ample visualizations:

- Table 1 focusses on the methodologies applied covering design science research, informing science, systems thinking, and knowledge evolution. It also references the efforts made to transform the progressing six levels referred to into a PKMS meta-framework of digital ecosystems interlinked with Popper's three Worlds and Nonaka's SECI \& Ba Model.

- Table 2 digs deeper into issues affecting knowledge workers and knowledge societies, including capacity-and-community-building, sustainable development, and key challenges. It also relates the PKMS ecosystems and SICEE model to Maslow's Extended Hierarchy of Needs.

- Table 3 describes sustainability-related efforts to re-purpose the publications and multiple visualized frameworks (already captured in their meme-based representations in the PKMS) to become learning assets (to exemplify opportunities for other content). It builds upon synergies with established learning management systems and proposes extensions to facilitate non-linear learning and novel ways of extelligence transfer and retention.

- Table 4 summarizes the entropy-and-generativity-related key rationales of the PKMS.

- Table 5 emphasizes the huge synergetic potential between traditional organizational KM and the personal KM concept and system in terms of, for example, human capital and organizational learning differentiations, heritage and innovation management, for example: the complementing workflows and prospects of twelve renowned dynamic knowledge creation models with the PKMS have also been mapped in a 'public transport-like' three-dimensional map; and the envisaged impact has been evaluated against sets of disruptive-innovation-criteria which demonstrates the PKMS's potential to become a general-purpose-technology.

Since the envisaged PKMS is still in its prototype-development stage, further empirical testing is necessary. Further research is in progress to determine how the PKMS concept compares to, can make use of and add to the advancing semantic web and AI technologies; this includes verifying the PKMS potential to generate ontologies and RDF-statements (resource description framework for knowledge modeling) straight from its content and relations repository. Publications are also planned to consider how the memetic PKMS storage compares to traditional document-centric approaches (e.g., Google Scholar, ResearchGate) and what kind of complementing, mutually beneficial synergies exist with current software and social platform or service-oriented computing providers, for example:

${ }^{16}$ Emerging Complexity describes states where "the solution to a problem is unknown, the problem statement itself is still unfolding, and the key stakeholders are not yet identified" (Kaiser et al., 2013).

${ }^{17}$ Isolated changes - as a KM Framework Cluster Analysis (Heisig, 2009) and the Change-Equilibrium Model (Leavitt, 1962) suggest - are likely to affect more than just one of four clusters (technologies: artefacts including storage devices; human factors: people, culture, leadership; organizational aspects: structures \& processes; tasks and management: operations and controlling). 
- The use of as-build-genealogies for authoring (but with resources not being depleted with use) correlates with the logics and logistics of Enterprise Resource and Supply Chain Management Systems.

- The storing, tracing, and repurposing of granular limited-size memes would fit well with Twitter functionalities.

- The more granular and transdisciplinary meme-to-meme traceabilities would greatly enhance reference management software and services (e.g. Google Scholar or ResearchGate) to save users precious time and efforts.

- The content stored in Google Books could be effectively used to validate the content, source, and location of memes uploaded by the PKMS community.

- Facebook users used to contribute content and chatter as social capital may appreciate to channel their energies (analogue to citizen science endeavors) into contributing to their own and others' heritage and novel knowledge.

- The professional world of Microsoft's LinkedIn would likewise profit but with the added community-related value of benefitting from and serving fellow knowledge workers representing diverse sets of gifts, contexts, means, and ends.

- LMSs and eLearning Portals offering traditional linear courses would profit from more flexible and exciting non-linear options where meme-based learning assets can be reused in other courses or transferred into the PKMS devices of participants or alumni for knowledge as well as customer retention.

This KM-related position paper has followed up on a typical Design Science Research project with multiple diverse milestones and publications along longitudinal streams of research with continually evolving design concepts and artefacts. It has applied the logic of a back-casting vision to frame prior findings and prospective work in a novel way in order to provide a comprehensive but concise overview to rationalize the need for a new generation of decentralized knowledge management systems. Developing knowledge by cumulative synthesis and by assessing the role of artefacts matters but also suffers from a lack of respective academic publications in the DSR as well as the KM domain ${ }^{18}$. This and the prior PKMS-related articles contribute to these underrepresented fields and to a research tradition of cumulative knowledge development. They aim is to inform designers and knowledge workers alike as well as to share the envisaged PKMS prospects with a wider critical mass of stakeholders as a prerequisite for creating the respective decentralized, more generative digital knowledge management reality.

18 An exploratory study focusing on Information Science (IS) and design theories refers to the lack of similar research and is also alarmed about the paucity of follow-up research that test or extend the IS design theories investigated which prevents the further evolution of the DSR field within and beyond the IS discipline (Schuster et al., 2018). An assessment of the role of KM artifacts (1997-2015) found that empirical works outnumbered conceptual contributions by two to one and, similarly, lacked cumulativeness and consistency in current KM debates (Mariano \& Awazu, 2016). 


\section{REFERENCES}

1. Beinhocker, E. D. (2006). The Origin of Wealth: Evolution, Complexity, and the Radical Remaking of Economics. Harvard Business Press.

2. Bjarneskans, H., Grønnevik, B., \& Sandberg, A. (1999). The lifecycle of memes. https://www.aleph.se/Trans/Cultural/Memetics/memecycle.html

3. Blass, E., \& Hayward, P. (2014). Innovation in higher education; will there be a role for "the academe/ university" in 2025? European Journal of Futures Research, 2(1), 41.

4. Boisot, M. (2004). Exploring the information space. University of Pennsylvania, 5-8.

5. Bratianu, C. (2019). Exploring Knowledge Entropy in Organizations. Management Dynamics in the Knowledge Economy, 7(3), 353-366.

6. Briscoe, G. (2010). Complex adaptive digital ecosystems. Proceedings of the International Conference on Management of Emergent Digital EcoSystems, 39-46.

7. $\quad$ Burt, R. S. (2004). Structural holes and good ideas. American Journal of Sociology, 110(2), 349_ 399.

8. Bush, V. (1945). As we may think. The Atlantic Monthy, 176(1), 101-108.

9. Bush, V. (1991). Memex revisited. From Memex to Hypertext, 197-216.

10. Cabitza, F., Simone, C., \& Cornetta, D. (2015). Sensitizing concepts for the next communityoriented technologies: Shifting focus from social networking to convivial artifacts. The Journal of Community Informatics, 11(2).

11. Cantner, U., \& Vannuccini, S. (2012). A new view of general purpose technologies. Jena Economic Research Papers.

12. Carvajal-Pérez, D., Araud, A., Chaperon, V., Le Masson, P., \& Weil, B. (2018). Generative Heritage: Driving Generativity through Knowledge Structures in Creative Industries. Lessons from Cuisine. 15th International Design Conference.

13. Ceruti, M., Williams, A., \& Bedford, D. (2019). Translating Knowledge Management Visions into Strategies. Emerald Publishing Limited.

14. Cohen, W. M., \& Levinthal, D. A. (1990). Absorptive capacity: A new perspective on learning and innovation. Administrative Science Quarterly, 128-152.

15. Collis, J. (2003). Memento-Introducing Memetics. Http://Meme. Sourceforge. Net/Docs/Memetics. Php. http://meme.sourceforge.net/docs/memetics.php

16. Dalkir, K. (2011). Knowledge Management in Theory and Practice. MIT Press.

17. Dawkins, R. (1976). The selfish gene. Oxford university press.

18. Drori, G. S. (2010). Globalization and technology divides: Bifurcation of policy between the "digital divide" and the "innovation divide." Sociological Inquiry, 80(1), 63-91.

19. Earl, M. (2001). Knowledge management strategies: Toward a taxonomy. Journal of Management Information Systems, 18(1), 215-233.

20. Eck, A. (2018). Generativity in digital ecosystems: How distributed networks organize for continuous change [PhD Thesis]. University of St. Gallen.

21. Eck, A., \& Uebernickel, F. (2016). Untangling Generativity: Two Perspectives on Unanticipated Change produced by Diverse Actors. ECIS, ResearchPaper35.

22. Erikson, E. (1950). Childhood and society. Norton, New York.

23. Florida, R. (2014). The Rise of the Creative Class-Revisited: Revised and Expanded. Hachette UK.

24. Frey, C. B., \& Osborne, M. (2013). The future of employment. How Susceptible Are Jobs to Computerisation.

25. Garnsey, E. (1998). A theory of the early growth of the firm. Industrial and Corporate Change, 7(3), 523-556.

26. Garon, J. M. (2011). Mortgaging the meme: Financing and managing disruptive innovation. Nw. J. Tech. \& Intell. Prop., 10, iii.

27. Gibson, J. J. (2014). The Ecological Approach to Visual Perception: Classic Edition. Psychology Press. 
28. Giebel, M. (2013). Digital divide, knowledge and innovations.

29. Gratton, L. (2011). The Shift: The Future of Work Is Already Here. Collins. https://books.google.de/books?id=q9yl9dF2ML8C

30. Heisig, P. (2009). Harmonisation of knowledge management-comparing $160 \mathrm{KM}$ frameworks around the globe. Journal of Knowledge Management, 13(4), 4-31.

31. Hevner, A. R., March, S. T., Park, J., \& Ram, S. (2004). Design science in information systems research. Management Information Systems Quarterly, 28(1), 6.

32. Johri, A., \& Pal, J. (2012). Capable and convivial design (CCD): A framework for designing information and communication technologies for human development. Information Technology for Development, 18(1), 61-75.

33. Kaiser, A. (2017). Towards a knowledge-based theory of developing sustainable visions: The theory wave. Proceedings of the 50th Hawaii International Conference on System Sciences, 4495-4504.

34. Kaiser, A., Feldhusen, B., \& Fordinal, B. (2013). Vision development as a knowledge creating process. 2013 46th Hawaii International Conference on System Sciences, 3593-3602.

35. Kanengisser, D. (2014). How ideas change and how they change institutions: A memetic theoretical framework.

36. Kerwin, A., \& Witte, M. (1983). Map of ignorance (Q-Cubed Programs): What is ignorance. https://ignorance.medicine.arizona.edu/about-us/what-ignorance

37. Kim, J., \& Oki, T. (2011). Visioneering: An essential framework in sustainability science. Sustainability Science, 6(2), 247-251.

38. Koch, R. (2001). The Power Laws of Business: The Science of Success. Nicholas Brealey.

39. Kolb, D. A. (2014). Experiential learning: Experience as the source of learning and development. FT press.

40. Koltko-Rivera, M. E. (2006). Rediscovering the later version of Maslow's hierarchy of needs: Self-transcendence and opportunities for theory, research, and unification. Review of General Psychology, 10(4), 302.

41. Kucharska, W. (2017). Relationships between trust and collaborative culture in the context of tacit knowledge sharing. Journal of Entrepreneurship, Management and Innovation, 13(4), 61-78.

42. Kucharska, W., \& Bedford, D. A. (2019). Knowledge Sharing and Organizational Culture Dimensions: Does Job Satisfaction Matter? Electronic Journal of Knowledge Management, 17(1), 1-18.

43. Laszlo, A. (2018). Education for the future: The emerging paradigm of thrivable education. World Futures, 1-10.

44. Laszlo, A., Luksha, P., \& Karabeg, D. (2017). Systemic innovation, education and the social impact of the systems sciences. Systems Research and Behavioral Science, 34(5), 601-608.

45. Leavitt, H. J. (1962). Applied Organizational Change in Industry: Structural, Technological and Humanistic Approaches. Carnegie Institute of Technology, Graduate School of Industrial Administration.

46. Levie, J., \& Lichtenstein, B. B. (2009). A final assessment of stages theory: Introducing a dynamic states approach to entrepreneurship.

47. Levy, P. (2011). The semantic sphere 1. Wiley New York.

48. Mariano, S., \& Awazu, Y. (2016). Artifacts in knowledge management research: A systematic literature review and future research directions. Journal of Knowledge Management, 20(6), 13331352.

49. Mintzberg, H. (2005). Developing theory about the development of theory. Great Minds in Management: The Process of Theory Development, 355-372.

50. Mynatt, E. D., O’day, V. L., Adler, A., \& Ito, M. (1998). Network communities: Something old, something new, something borrowed... Computer Supported Cooperative Work (CSCW), 7(1-2), 123-156.

51. Nielsen, M. (2012). Reinventing Discovery: The New Era of Networked Science. Princeton University Press. 
52. Nonaka, I., \& Toyama, R. (2005). The theory of the knowledge-creating firm: Subjectivity, objectivity and synthesis. Industrial and Corporate Change, 14(3), 419-436.

53. Nonaka, I., Toyama, R., \& Konno, N. (2000). SECI, Ba and leadership: A unified model of dynamic knowledge creation. Long Range Planning, 33(1), 5-34.

54. O'Raghallaigh, P., Sammon, D., \& Murphy, C. (2011). The design of effective theory. Systems, Signs \& Actions, 5(1), 117-132.

55. Pasher, E., \& Ronen, T. (2011). The Complete Guide to Knowledge Management: A Strategic Plan to Leverage Your Company's Intellectual Capital. John Wiley \& Sons.

56. Pinheiro, F. A. (2004). Requirements traceability. In Perspectives on software requirements (pp. 91113). Springer.

57. Pirolli, P., \& Card, S. (2005). The sensemaking process and leverage points for analyst technology as identified through cognitive task analysis. Proceedings of International Conference on Intelligence Analysis, 5, 2-4.

58. Pollard, D. (2008). PKM: A bottom-up approach to knowledge management. Knowledge Management in Practice: Connections and Context, 95-109.

59. Popper, K. (1978). Three Worlds: The Tanner Lecture on Human Values: Delivered at the University of Michigan. The Tanner Lectures, Humanities Center, University of Utah-Http://Tinyurl. Com/Yjf7n3x.

60. Rahimi, E. (2015). A design framework for personal learning environments [PhD Thesis]. Ph. D. thesis, Delft University of Technology, The Netherlands.

61. Roszkowska-Menkes, M. (2017). User Innovation: State of the Art and Perspectives for Future Research. Journal of Entrepreneurship, Management and Innovation, 13(2), 127-154.

62. Rylander, A. (2009). Design thinking as knowledge work: Epistemological foundations and practical implications. Design Management Journal, 4(1), 7-19.

63. Schmitt, U. (2014a). Making sense of e-skills at the dawn of a new personal knowledge management paradigm. Proceedings of the E-Skills for Knowledge Production and Innovation Conference, 417-447. http://proceedings.e-skillsconference.org/2014/e-skills417-447Schmitt815.pdf

64. Schmitt, U. (2014b). Personal knowledge management devices-The next co-evolutionary driver of human development. International Conference on Education and Social Sciences (INTCESS14), 1081-1091. http://www.ocerint.org/cd/abstracts/a384.pdf

65. Schmitt, U. (2015a). Quo Vadis, Knowledge Management: A Regeneration or a Revolution in the Making? Journal of Information \& Knowledge Management, 14(04), 1550030.

https://doi.org/10.1142/S0219649215500306

66. Schmitt, U. (2015b). Supporting digital scholarship and individual curation based on a memeand-cloud-based personal knowledge management concept. Academic Journal of Science (AJS), 4(1), 220-237. http://www.universitypublications.net/ajs/0401/pdf/R4ME489.pdf

67. Schmitt, U. (2015c). Towards a 'world heritage of memes repository'for tracing ideas, tailoring knowledge assets and tackling opportunity divides: Supporting a novel personal knowledge management concept. The International Journal of Technology, Knowledge \& Society: Annual Review, 10(2015), 25-44. https://doi.org/10.18848/1832-3669/CGP/v10/56516

68. Schmitt, U. (2016a). Design science research for personal knowledge management system development-revisited. Informing Science, 19(1), 345-379. https://doi.org/10.28945/3566

69. Schmitt, U. (2016b). Personal knowledge management for development (PKM4D) framework and its application for people empowerment. Procedia Computer Science, 99, 64-78.

https://doi.org/10.1016/j.procs.2016.09.101

70. Schmitt, U. (2016c). Redefining knowledge management education with the support of personal knowledge management devices. In V. L. Uskov, R. J. Howlett, \& L. C. Jain (Eds.), Smart Education and e-Learning 2016 (Vol. 59, pp. 515-525). Springer. dx.doi.org/10.1007/978-3-31939690-3_46

71. Schmitt, U. (2016d). Tools for Exploration and Exploitation Capability: Towards a Co-evolution of Organizational and Personal Knowledge Management Systems. International Journal of 
Knowledge, Culture \& Change in Organizations: Annual Review, 15, $23-47$. https://doi.org/10.18848/1447-9524/CGP/23-47

72. Schmitt, U. (2017a). Devising enabling spaces and affordances for personal knowledge management system design. Informing Science, 20, 63-82. https://doi.org/10.28945/3743

73. Schmitt, U. (2017b). Mapping the territory for a knowledge-based system. Lecture Notes in Computer Science (Including Subseries Lecture Notes in Artificial Intelligence and Lecture Notes in Bioinformatics), 10448 LNAI, 3-13. https://doi.org/10.1007/978-3-319-67074-4_1

74. Schmitt, U. (2017c). The Logic of Use and Functioning of Personal KM-supported Experience Management. CEUR Workshop Proceedings (CEUR-WS), 1821, 62-77.

https://doi.org/urn:nbn:de:0074-1821-6

75. Schmitt, U. (2017d). Shortcomings of the web of documents and data for managing personal knowledge and collaboration. Next Generation Computing Applications (NextComp), 2017 1st International Conference On, 23-29. https://doi.org/10.1109/NEXTCOMP.2017.8016171

76. Schmitt, U. (2018a). From Ignorance Map to Informing PKM4E Framework: Personal Knowledge Management for Empowerment. Issues in Informing Science and Information Technology, 15, 125-144. https://doi.org/10.28945/4017

77. Schmitt, U. (2018b). Rationalizing a Personalized Conceptualization for the Digital Transition and Sustainability of Knowledge Management Using the SVIDT Method. Sustainability, 10(3), 839. https://doi.org/10.3390/su10030839

78. Schmitt, U. (2018c). Supporting the Sustainable Growth of SMEs with Content-and Collaboration-based Personal Knowledge Management Systems. Journal of Entrepreneurship and Innovation in Emerging Economies, 4(1), 1-21. https://doi.org/10.1177/2393957517739773

79. Schmitt, U. (2019a). Decentralizing knowledge management: Affordances and impacts. The Electronic Journal of Knowledge Management (EJKM), 17(2), 114-130. http://www.ejkm.com/issue download.html?idArticle $=876$

80. Schmitt, U. (2019b). Designing Decentralized Knowledge Management Systems to Effectuate Individual and Collective Generative Capacities. Kybernetes, 49(1), 22-46. https://doi.org/10.1108/K-03-2019-0215

81. Schmitt, U. (2019c). Interoperability of Managing Knowledge and Learning Processes for Sustainable eEducation. 1-6. https://doi.org/10.1109/NEXTCOMP.2019.8883671

82. Schmitt, U. (2019d). Knowledge Management Decentralization as a Disruptive Innovation and General-Purpose-Technology. Proceedings of the 20th European Conference on Knowledge Management, 2, 923-932. https://www.researchgate.net/publication/334431858

83. Schmitt, U. (2020a). (Neg)Entropic Scenarios Affecting the Wicked Design Spaces of Knowledge Management Systems. Entropy, 22(2), 169. https://doi.org/10.3390/e22020169

84. Schmitt, U. (2020b). Scalability of Generative Knowledge Management Systems: Designing for Individuals' and Institutions' Mutual Benefit. Kybernetes, article-in-press.

85. Schmitt, U. (2020c). Systems Dynamics and Activity-Based Modeling to Blueprint Generative Knowledge Management Systems. International Journal of Modeling and Optimization (IJMO), inpress.

86. Schmitt, U., \& Butchart, B. A. (2014). Making Personal Knowledge Management Part and Parcel of Higher Education Programs and Services Portfolios. Journal of the World Universities Forum, 6(4), 87-103. https://doi.org/10.18848/1835-2030/CGP/v06i04/59518

87. Schmitt, U., \& Gill, T. G. (2019). Synthesizing Design and Informing Science Rationales for Driving a Decentralizing Knowledge Management Agenda. Informing Science: The International Journal of an Emerging Transdiscipline, 22, 1-18. https://doi.org/10.28945/4264

88. Schmitt, U., \& Gill, T. G. (2020). Entropy, Generativity, and Rugged Fitness Landscapes as the Means to Rationalize a Paradigm Shift in Knowledge Management. InSITE 2020: Informing Science + IT Education Conferences, InSITE 2020, 061-078. https://doi.org/10.28945/4566 
89. Schmitt, U., \& Saadé, R. G. (2017). Taking on opportunity divides via smart educational and personal knowledge management technologies. Proceedings of the 12th International Conference on E-Learning (ICEL), 188-196. https:// books.google.com.np/books?id=2R8zDwAAQBAJ

90. Scholz, R. W. (2017). Digital threat and vulnerability management: The SVIDT method. Sustainability, 9(4), 554.

91. Schuster, R., Wagner, G., \& Schryen, G. (2018). Information Systems Design Science Research and Cumulative Knowledge Development: An Exploratory Study.

92. Simon, H. A. (1971). Designing organizations for an information-rich world.

93. Snowden, D. (2002). Complex acts of knowing: Paradox and descriptive self-awareness. Journal of Knowledge Management, 6(2), 100-111.

94. Star, S. L. (2010). This is not a boundary object: Reflections on the origin of a concept. Science, Technology, \& Human Values, 35(5), 601-617.

95. Stewart, I., \& Cohen, J. (1999). Figments of Reality: The Evolution of the Curious Mind. Cambridge University Press.

96. Szostak, R., Gnoli, C., \& López-Huertas, M. (2016). Interdisciplinary Knowledge Organization. Springer.

97. Sztompka, P. (2019). Trust in the moral space. In Trust in Contemporary Society (pp. 31-40). Brill.

98. Usher, A. P. (1954). A History of Mechanical Inventions. Courier Corporation.

99. Wiek, A., \& Iwaniec, D. (2014). Quality criteria for visions and visioning in sustainability science. Sustainability Science, 9(4), 497-512.

100. Wierzbicki, A. P., \& Nakamori, Y. (2007). Creative environments: Issues of creativity support for the knowledge civilization age (Vol. 59). Springer.

101. Wiig, K. M. (2011). The importance of personal knowledge management in the knowledge society. Personal Knowledge Management, 229-262.

102. World Bank Group. (2016). World development report 2016: Digital dividends. World Bank Publications.

\section{AUTHOR'S BIOGRAPHY}

Ulrich Schmitt's professional background includes IT and management consultant positions (London, Basle), professor and vice president at two independent German universities, Vice Rector (Polytechnic of Namibia) and Dean of the Graduate School (University of Botswana). He studied Management and Industrial Engineering (TU Berlin, Cranfield University), completed his PhD (Basle University) and a Science \& Research Management Program (Speyer University). Focusing on Knowledge Management, he is currently Professor at the University of Stellenbosch Business School. 